\title{
AKREDYTOWANIE RYNKU USEUG EDUKACYJNYCH. AKTUAlne ROZWIĄZANIA PRAWNE NA PRZYKŁADZIE PLACóWEK KSZTAŁCENIA USTAWICZNEGO
}

\section{Wstęp}

Globalny rozwój we wszystkich dziedzinach życia społecznego nieustannie przyczynia się do konieczności ciągłego podnoszenia kwalifikacji. Aktualnie posiadanie szerokiej wiedzy i dysponowanie rozległymi umiejętnościami stanowi o miejscu człowieka w społeczeństwie, a zarazem pozwala realizować jego indywidualne plany i pasje ${ }^{1}$. W związku z powyższym odnotowuje się znaczne rozszerzenie się rynku usług edukacyjnych, wzrost ilości ofert szkoleniowych oraz zainteresowanie kształceniem ustawicznym, zwłaszcza w formach pozaszkolnych. Częściowe uwolnienie rynku edukacyjnego i znaczne zróżnicowanie oferty kształcenia ustawicznego stwarza konieczność dokonywania oceny działalności instytucji prowadzących tego typu kształcenie. Oczywistym jest jak duże znaczenie ma stosowanie odpowiednich narzędzi, które mogą zagwarantować potencjalnym słuchaczom usługi edukacyjne na optymalnym jakościowo poziomie. Jednym z instrumentów, za pomocą którego można ocenić jakość kształcenia ustawicznego, jest akredytacja². Nieulega wątpliwości, że w dobie szybkiego wzrostu usług edukacyjnych

* Dr hab., prof. Katolickiego Uniwersytetu Lubelskiego Jana Pawła II; e-mail: magdalena.pyter@kul.pl, https:/ / orcid.org/0000-0002-2203-0185.

1 S.M. Halonen, T. Lomas, A passionate way of being. A qualitative study revealing the passion spiral, International Journal of Psychological Research 2014, t. 7, nr 2, s. 20.

2 Por. Ministerstwo Edukacji Narodowej, Przewodnik procedur akredytacji placówek prowadzacych kształcenie ustawiczne w formach pozaszkolnych, Warszawa 2005, s. 4. 
przyczynia się ona do trwałego zapewniania nauczania o "dobrej jakości" ${ }^{3}$.

Instytucje edukacyjne działające w warunkach rynkowych, korzystając z możliwości, jakie dają przepisy prawne, powinny dbać o satysfakcjonujący poziom usług edukacyjnych. Pozytywna ocena jakości pozwala bowiem - poza ugruntowaną pozycją na rynku - decydować o popycie na tego typu usługi. W warunkach gospodarki rynkowej tylko akredytowane, a więc najlepsze jakościowo placówki mają szansę na szerokie upublicznienie informacji o placówce. Warto także mieć na uwadze fakt, że każda uzyskana akredytacja to również wpływ i działanie poszczególnych instytucji i osób ${ }^{4}$.

Przedmiotem artykułu jest akredytacja. W poszczególnych systemach, w których funkcjonują różnorodne podmioty, akredytacja będąca narzędziem oceny ich działalności jest niezwykle istotna lub wręcz konieczna. Tytuł artykułu odnosi się do rynku usług edukacyjnych, stanowiących część systemu oświaty, zaś przykładowe odniesienie się do placówek kształcenia ustawicznego i regulacji prawnych ich tylko dotyczących konkretyzuje zagadnienie zawarte $\mathrm{w}$ tytule.

Celem niniejszego tekstu jest analiza aktualnych procedur prawnych związanych z uzyskaniem akredytacji na przykładzie placówek kształcenia ustawicznego oraz rozstrzygnięcie problemu, czy w warunkach wolnego rynku usług edukacyjnych zasadna jest - zgodnie z aktualnym stanem prawnym - fakultatywność przy ubieganiu się o uzyskanie akredytacji, czy też lepszym rozwiązaniem - z punktu widzenia dbałości o jakość kształcenia - byłaby obligatoryjność w przedmiocie ubiegania się o akredytację. W artykule zastosowano metodę formalno-dogmatyczną, co pozwoliło na zbadanie materiału normatywnego i jego konfrontację z rzeczywistością.

Trzeba mieć świadomość, że problematyka kształcenia ustawicznego jest wprawdzie przedmiotem szerokiej analizy, jednak głównie na płaszczyźnie poszczególnych dyscyplin pedagogiki ${ }^{5}$. Tam jednak nie podnosi

3 Por. K. Szewior, Akredytacja w niemieckim szkolnictwie wyższym, Warszawa 2018, s. 36.

4 E. Drogosz-Zabłocka, B. Minkiewicz, System zapewnienia jakości kształcenia, w: Edukacja dla pracy, red. U. Sztanderska, E. Drogosz-Zabłocka, B. Minkiewicz, Warszawa 2007, s. 48.

5 Np.: W. Jakubaszek, Człowiek w kontekście całożyciowej edukacji. Teoria i praktyka. Wybrane zagadnienia, Kraków 2016; Kształcenie zawodowe i ustawiczne a potrzeba rynku, red. B. Wołosiuk, M. Nowak, Biała Podlaska 2012; Społeczne skutki zmiany oświatowej w Polsce, red. M. Niezgoda, Kraków 2011. 
się problematyki tak szczegółowej, jak akredytacja, warunki konieczne do jej spełnienia oraz korzyści z tego wynikające. Z punktu widzenia prawa, które jest głównym regulatorem przedmiotowego zagadnienia, niemal zupełnie brakuje komentarzy i oceny.

\section{Zasady kształcenia ustawicznego}

Warto zwrócić uwagę na to, że podstawą optymalnie funkcjonującego kształcenia ustawicznego, jak również poszczególnych jego elementów, w szczególności akredytacji, powinna być odpowiednio skonstruowana norma prawna. Dopiero bowiem na kanwie przepisu prawa można budować in genere instytucję kształcenia ustawicznego. Analizując przepisy prawa polskiego odnoszące się do problematyki kształcenia ustawicznego, należy głównie zwrócić uwagę na obowiązującą od września 2017 r. ustawę Prawo oświatowe ${ }^{6}$, jak również poszczególne akty wykonawcze. To na tych aktach prawnych spoczywa problem poszczególnych rozstrzygnięć, które powinny skutkować odpowiednim funkcjonowaniem kształcenia ustawicznego. Co do samego zagadnienia kształcenia ustawicznego ustawodawca raczej marginalnie odniósł się do przedmiotowego zagadnienia, poświęcając mu niewiele uwagi ${ }^{7}$. Warto natomiast podkreślić, że aktualne przepisy formułują definicję legalną kształcenia ustawicznego, zgodnie z którą pod tym pojęciem należy rozumieć kształcenie w szkołach dla dorosłych, branżowych szkołach II stopnia i szkołach policealnych, a także uzyskiwanie i uzupełnianie wiedzy, umiejętności i kwalifikacji zawodowych w formach pozaszkolnych przez osoby, które spełniły obowiązek szkolny ${ }^{8}$.

6 Ustawa z dnia 14 grudnia 2016 r. - Prawo oświatowe, tekst jednolity: Dz. U. z 2019 r. poz. 1148, 1078, 1287, 1680, 1681.

7 Problem lakonicznego podejścia ustawodawcy do przedmiotowego zagadnienia jest dostrzegany w literaturze specjalistycznej. Por. np. komentarz do tezy 1 art. 118, M. Pilich, Prawo oświatowe oraz przepisy wprowadzające. Komentarz, red. A. Olszewski, Warszawa 2017, https://sip.lex.pl/\#/commentary/587750401/547841?keyword=Pilich\&tocHit=1\& cm=STOP [dostęp: 20.10.2019 r.], gdzie redaktorzy publikacji zwracają uwagę, że: „Ta definicja [kształcenia ustawicznego - przyp. autora] niewiele wyjaśnia z istoty omawianego pojęcia, należy zatem sięgnąc do dorobku nauk pedagogicznych".

8 Art. 4 pkt 30 ustawy z dnia 14 grudnia 2016 r. - Prawo oświatowe. Według aktualnej definicji pozaprawnej „[...] głównym zadaniem edukacji ustawicznej jest wychowanie 
Kształcenie ustawiczne może być prowadzone w formach pozaszkolnych realizowanych przez publiczne i niepubliczne placówki kształcenia ustawicznego i centra kształcenia zawodowego oraz publiczne i niepubliczne szkoły prowadzące kształcenie zawodowe ${ }^{9}$. Godny podkreślenia jest fakt, że ustawodawca delegował ministra właściwego do spraw oświaty do określenia, w drodze rozporządzenia, szczegółowej problematyki dotyczącej kształcenia ustawicznego ${ }^{10}$.

Przywołany powyżej akt prawny wykonawczy precyzuje, że publicznymi placówkami kształcenia ustawicznego są centra kształcenia ustawicznego ${ }^{11}$. Publiczne placówki i ośrodki mogą współpracować z pracodawcami w zakresie: organizacji i prowadzenia kształcenia praktycznego, przygotowania oferty kształcenia $\mathrm{w}$ formach pozaszkolnych, zgodnej z oczekiwaniami pracodawców, kształcenia ustawicznego pracowników; urzędami pracy w zakresie szkolenia osób zarejestrowanych w tych urzędach, jak również innymi podmiotami prowadzącymi kształcenie ustawiczne $\mathrm{w}$ zakresie zadań statutowych ${ }^{12}$. Warto zaznaczyć, że nie ma możliwości akredytowania placówek kształcenia ustawicznego prowadzącego przez inne podmioty niż te, które są wyraźnie wskazane przez ustawodawcę.

Kształcenie ustawiczne może być prowadzone $w$ formie stacjonarnej lub zaocznej, także przy wykorzystaniu technik kształcenia na odległość ${ }^{13}$. Kształcenie ustawiczne prowadzi się w następujących formach

nowego typu człowieka, charakteryzującego się twórczym i dynamicznym stosunkiem do życia i kultury; człowieka, który potrafi doskonalić siebie, zmieniać warunki życia i ulepszać je dla dobra człowieka", J. Półturzycki, Kształcenie ustawiczne i jego konsekwencje dla edukacji, w: Ksztatcenie ustawiczne. Idee i doświadczenia, red. Z.P. Kruszewski, J. Półturzycki, E.A. Wesołowska, Płock 2003, s. 46.

9 Art. 117 ust. 1 ustawy z dnia 14 grudnia 2016 r. - Prawo oświatowe. Wszystkie z wymienionych funkcjonują w systemie oświaty. Por. Prawo administracyjne, red. M. Wierzbowski, wyd. 13, Warszawa 2017, s. 545.

10 Rozporządzenie Ministra Edukacji Narodowej z dnia 19 marca 2019 r. w sprawie kształcenia ustawicznego w formach pozaszkolnych, Dz. U. z 2019 r. poz. 652.

$11 \S 3$ rozporządzenia w sprawie kształcenia ustawicznego $\mathrm{w}$ formach pozaszkolnych.

$12 \S 7$ rozporządzenia w sprawie kształcenia ustawicznego w formach pozaszkolnych. Co do szczegółów zob. także: rozporządzenie Ministra Edukacji Narodowej z dnia 14 lutego 2019 r. w sprawie ramowych statutów: publicznej placówki kształcenia ustawicznego oraz publicznego centrum kształcenia zawodowego, Dz. U. z 2019 r. poz. 320.

13 Szerzej zob. D. Dziewulak, Ksztatcenie na odległość w wybranych państwach europejskich, Analizy BAS 2012, t. 85, nr 18 s. 3-4; S. Juszczyk, Edukacja na odległość. Kodyfikacja pojęć, 
pozaszkolnych: kwalifikacyjny kurs zawodowy, kurs umiejętności zawodowych, kurs kompetencji ogólnych, turnus dokształcania teoretycznego młodocianych pracowników, a także kursy inne niż wymienione powyżej, umożliwiające uzyskiwanie i uzupełnianie wiedzy, umiejętności i kwalifikacji zawodowych ${ }^{14}$.

Na podmioty prowadzące kształcenie ustawiczne w formach pozaszkolnych rozporządzenie nałożyło obowiązek zapewnienia odpowiednich warunków procesu dydaktycznego. I tak, warunkiem koniecznym jest zatrudnianie kadry o odpowiednich kwalifikacjach ${ }^{15}$. Ponadto wymagane jest posiadanie odpowiednich pomieszczeń wyposażonych w sprzęt i pomoce dydaktyczne umożliwiające prawidłową realizację kształcenia, zapewnienie bezpiecznych i higienicznych warunków pracy i nauki, warunków organizacyjnych i technicznych na takim poziomie, który umożliwia udział w kształceniu osobom niepełnosprawnym. Jako ostatni element ustawodawca wymienił nadzór służący podnoszeniu jakości prowadzonego kształcenia ${ }^{16}$.

Kształcenie ustawiczne $\mathrm{w}$ formach pozaszkolnych prowadzone jest na podstawie programu nauczania, który zawiera: nazwę formy kształcenia; czas trwania, liczbę godzin kształcenia i sposób jego organizacji; wymagania wstępne dla uczestników i słuchaczy, które w przypadku słuchaczy kwalifikacyjnych kursów zawodowych i uczestników kursów umiejętności zawodowych uwzględniają także szczególne uwarunkowania lub ograniczenia związane $\mathrm{z}$ kształceniem w danym zawodzie, określone w przepisach w sprawie klasyfikacji zawodów szkolnictwa zawodowego; cele kształcenia i sposoby ich osiągania z uwzględnieniem możliwości indywidualizacji pracy słuchaczy kwalifikacyjnych kursów zawodowych lub uczestników kształcenia w innych formach pozaszkolnych, w zależności od ich potrzeb i możliwości; plan nauczania określający nazwę zajęć oraz ich wymiar; treści nauczania w zakresie poszczególnych zajęć; opis

\footnotetext{
regut i procesów, Warszawa 2002, s. 124.

14 Art. 117 ust. 1a ustawy z dnia 14 grudnia 2016 r. - Prawo oświatowe.

15 Zob. art. 9 ust. 2 ustawy z dnia 26 stycznia 1982 r. - Karta Nauczyciela, Dz. U. z 2018 r. poz. 967 i 2245 oraz rozporządzenie Ministra Edukacji Narodowej z dnia 1 sierpnia 2017 r. w sprawie szczegółowych kwalifikacji wymaganych od nauczycieli, Dz. U. z 2017 r. poz. 1575.

16 Por. § 23 ust. 1 rozporządzenia w sprawie kształcenia ustawicznego w formach pozaszkolnych.
} 
efektów kształcenia; wykaz literatury oraz niezbędnych środków i materiałów dydaktycznych; sposób i formę zaliczenia ${ }^{17}$.

Przedstawione powyżej zagadnienia stanowią zespół kryteriów, które warunkują, że uprawniony podmiot może realizować kształcenie ustawiczne. Nie ulega wątpliwości fakt, iż wykorzystanie dostępnego w przepisach prawa i praktyce narzędzia, jakim jest akredytacja, powinno być gwarantem przesądzającym o jakości prowadzenia tego typu kształcenia. Warto też zwrócić uwagę, że o ile przywoływane w tekście rozporządzenie szeroko odnosi się do placówek publicznych, o tyle organizacja placówek niepublicznych nie znalazła należytej uwagi ustawodawcy. Uzyskanie przez nie akredytacji jest oczywiście możliwe, głównie na zasadzie analogii do placówek publicznych. Wydaje się więc, że placówkom niepublicznym tym bardziej powinno zależeć na uwiarygodnieniu prowadzonego przez nie procesu kształcenia.

\section{Postępowanie o przyznanie akredytacji placówkom kształcenia ustawicznego}

Problematykę akredytowania publicznych i niepublicznych placówek kształcenia ustawicznego, placówek kształcenia praktycznego oraz ośrodków dokształcania i doskonalenia zawodowego, prowadzących kształcenie ustawiczne $w$ formach pozaszkolnych, reguluje art. 118 ustawy Prawo oświatowe. Czyni to również wydane na podstawie przywołanego przepisu ustawy rozporządzenie Ministra Edukacji Narodowej z dnia 29 sierpnia 2019 r. w sprawie akredytacji kształcenia ustawicznego w formach pozaszkolnych ${ }^{18}$.

Zgodnie z głosem orzecznictwa prawo do ubiegania się o uzyskanie akredytacji przysługuje: publicznym i niepublicznym placówkom funkcjonującym $\mathrm{w}$ ramach systemu oświaty. Wynika $\mathrm{z}$ tego, że katalog podmiotów mogących ubiegać się o akredytację jest określony przez

$17 \S 25$ rozporządzenia w sprawie kształcenia ustawicznego w formach pozaszkolnych. Por. np. Modelowy program nauczania dla kwalifikacyjnego kursu zawodowego w zakresie kwalifikacji A.35. Ksztatcenie ustawiczne w formach pozaszkolnych. Program o strukturze modutowej, https:/ /efs.men.gov.pl/wp-content/uploads/2018/04/A.35.pdf [dostęp: 01.09.2019 r.].

18 Dz. U. z 2019 r. poz. 1692. 
ustawodawcę w sposób pozytywny ${ }^{19}$. Zasadniczym celem uzyskania akredytacji jest potwierdzenie spełniania przez dane placówki określonych wymogów i zapewnienia wysokiej jakości prowadzonego kształcenia ${ }^{20}$. Tak określony cel przepisu przede wszystkim uprawnił ustawodawcę do określenia, jakie podmioty mogą się ubiegać o jej przyznanie ${ }^{21}$. Z punktu widzenia potencjalnego uczestnika kształcenia ustawicznego tak sformułowane cele dają zaś gwarancję, że podjęta edukacja będzie miała odpowiedni poziom, zatem cele te wydają się logiczne i warte podejmowania określonych czynności, by je osiągnąć.

Ubieganie się o akredytację wymaga spełniania przez placówkę lub ośrodek określonych kryteriów. I tak, podmioty te muszą prowadzić kształcenie w formie lub formach pozaszkolnych przez okres co najmniej trzech lat; opracować i stosować system zapewniania jakości kształcenia oraz systematycznie go doskonalić; zapewniać bazę wyposażoną w środki dydaktyczne - w zakresie danej formy pozaszkolnej; zapewniać wykwalifikowaną kadrę - w zakresie danej formy pozaszkolnej; zapewniać program nauczania w zakresie danej formy pozaszkolnej; zapewniać warunki realizacji praktycznej nauki zawodu - w przypadku ubiegania się o akredytację na kształcenie w formach pozaszkolnych; zapewniać bezpieczne i higieniczne warunki realizacji kształcenia w danej formie pozaszkolnej oraz udostępniać uczestnikom danej formy pozaszkolnej materiały dydaktyczne ${ }^{22}$.

Nietrudno odnieść wrażenie, że przedstawione powyżej warunki sine qua non nie można uznać za ostre i jednoznaczne w interpretacji. Przynajmniej część z nich, jak np. zapewnianie oraz doskonalenie jakości kształcenia, zapewnienie odpowiednio wyposażonej bazy dydaktycznej czy warunków do nauki zawodu, powinny być jasno określone. Analogicznie, za rozwiązanie zmierzające $\mathrm{w}$ kierunku obniżenia poziomu jakości należy uznać fakt, że aktualne przepisy nie zawierają rozwiązania, które ustawa Prawo oświatowe obejmowała przed ostatnią nowelizacją.

19 Wyrok WSA w Warszawie z dnia 3 października 2008 r., I SA/Wa 638/08, LEX nr 521226.

20 Por. M. Pyter, A. Balicki, Prawo oświatowe. Komentarz, Warszawa 2017, s. 375.

21 Należy podkreślić, że ustawa nie ogranicza możliwości prowadzenia działalności oświatowej, określa jedynie, kto może ubiegać się o uzyskanie akredytacji prowadzonego kształcenia. Zob. Wyrok WSA w Warszawie z dnia 3 października 2008 r., I SA/Wa 638/08, LEX nr 521226.

${ }^{22}$ Art. 118 ust. 3 ustawy z dnia 14 grudnia 2016 r. - Prawo oświatowe. 
Zgodnie z uchylonym już ust. 4 art. 118 w postępowaniu o uzyskanie akredytacji kurator oświaty uwzględniał także wyniki nadzoru pedagogicznego sprawowanego nad placówką lub ośrodkiem. W tej sytuacji należy zgodzić się z autorem publikacji z zakresu prawa oświatowego, że dotychczasowe rozstrzygnięcia w ten właśnie sposób nie dopuszczały, mimo iż nie czyniły tego expressis verbis, na akredytowanie placówki nowo tworzonej $j^{23}$.

Taki stan rzeczy nasuwa wręcz konieczność sformułowania postulatów de lege ferenda. Przede wszystkim nieodzowne wydaje się szczegółowe doprecyzowanie pojęć niedookreślonych w taki sposób, żeby nie budziły one żadnych wątpliwości. Ponadto zdecydowanie bardziej uzasadniona wydaje się teza, by w postępowaniu o uzyskanie akredytacji kurator oświaty uwzględniał wyniki nadzoru pedagogicznego sprawowanego nad placówką lub ośrodkiem. Nadzór pedagogiczny jest narzędziem używanym do pomiaru jakości procesu edukacyjnego, co mogłoby stanowić dodatkowy atut przy ubieganiu się o akredytację, a dodatkowo placówka wnioskująca o przyznanie tego certyfikatu musiałaby się już legitymować jakimś okresem działania ${ }^{24}$.

Samo wszczęcie postępowania akredytacyjnego inicjowane jest zawsze w oparciu o wniosek zainteresowanego podmiotu. Wniosek o przyznanie akredytacji na kształcenie ustawiczne $w$ danej formie pozaszkolnej dyrektor placówki w uzgodnieniu z organem prowadzącym placówkę składa do kuratora oświaty właściwego ze względu na miejsce prowadzenia kształcenia ustawicznego w danej formie pozaszkolnej ${ }^{25}$. Z punktu widzenia przepisu prawnego wniosek powinien zawierać elementy konieczne, które będą warunkowały o podjęciu procedowania w przedmiocie akredytowania placówki. I tak, do wniosku należy dołączyć: akt założycielski placówki publicznej albo zaświadczenie o wpisie placówki niepublicznej do ewidencji placówek niepublicznych prowadzonej przez

23 Por. Teza 3 do art. 118 (in fine), Prawo oświatowe oraz przepisy wprowadzające. Komentarz, red. M. Pilich, A. Olszewski, Warszawa 2017, https://sip.lex.pl/\#/commentary/587 750401/547841?keyword=Pilich\&tocHit=1\&cm=STOP [dostęp: 20.10 .2019 r.].

${ }^{24}$ Co do realizacji nadzoru pedagogicznego zob. rozporządzenie Ministra Edukacji Narodowej z dnia 25 sierpnia 2017 r. w sprawie nadzoru pedagogicznego, Dz. U. z 2017 r. poz. 1658 z późn. zm.

25 § 3 ust. 1 rozporządzenia Ministra Edukacji Narodowej z dnia 29 sierpnia 2019 r. w sprawie akredytacji kształcenia ustawicznego w formach pozaszkolnych, Dz. U. z 2019 r. poz. 1692. 
jednostkę samorządu terytorialnego; zaświadczenie o wpisie do ewidencji działalności gospodarczej lub odpis z rejestru przedsiębiorców; statut placówki; własną ocenę działalności placówki w ostatnim roku w zakresie kształcenia zgłoszonego do akredytacji, opracowaną przez osobę kierującą placówką; dowód wniesienia opłaty ${ }^{26}$ albo oświadczenie, że placówka całość kształcenia prowadzi nieodpłatnie ${ }^{27}$.

Obowiązkiem kuratora jest powołanie zespołu akredytacyjnego, którego zadaniem będzie ocena działalności placówki zgodnie z wytycznymi przedstawionymi powyżej. Skład zespołu oceniającego powinien być jak najbardziej niezależny od osoby wnioskodawcy. Tylko bowiem takie rozwiązanie zagwarantuje autonomię $\mathrm{w}$ podejmowaniu decyzji i wystawieniu oceny. $W$ tym kontekście poprawne wydaje się rozwiązanie zaproponowane $\mathrm{w}$ rozporządzeniu wykonawczym. Zgodnie $\mathrm{z}$ nim w skład zespołu akredytacyjnego powinni wejść dwaj przedstawiciele kuratora oświaty wyznaczeni spośród pracowników kuratorium oświaty, przy czym do zadań jednego z nich będzie należało pełnienie funkcji przewodniczącego komisji. Ponadto zespół składa się z: przedstawiciela wojewódzkiego urzędu pracy, w przypadku ubiegania się o przyznanie akredytacji przez placówkę publiczną prowadzoną przez powiat; przedstawiciela powiatowego urzędu pracy właściwego ze względu na siedzibę placówki, przy czym dotyczy to ubiegania się o przyznanie akredytacji przez placówkę inną niż prowadzoną przez powiat; przedstawiciela organizacji pracodawców wyłonionego spośród kandydatów zgłoszonych przez te organizacje. Ciekawym rozwiązaniem - i zdecydowanie działającym na korzyść wnioskującego - jest możliwość powołania do składu komisji oceniającej specjalisty w zakresie określonej dziedziny wiedzy. Powołania takiego dokonuje kurator oświaty na wniosek przewodniczącego zespołu akredytacyjnego ${ }^{28}$. Opracowanie programu i wyznaczenie terminu wizyty akredytacyjnej należy do obowiązków przewodniczącego zespołu akredytacyjnego.

26 Bazowa wysokość opłaty podlega corocznej waloryzacji średniorocznym wskaźnikiem cen towarów i usług konsumpcyjnych ogółem. Wysokość tejże opłaty jest podawana przez kuratora oświaty do publicznej wiadomości do dnia 31 grudnia każdego roku. Na rok 2019 została ona ustalona na poziomie 1023 zł.

27 § 3 ust. 3 rozporządzenia w sprawie akredytacji kształcenia ustawicznego w formach pozaszkolnych.

$28 \S 5$ rozporządzenia w sprawie akredytacji kształcenia ustawicznego w formach pozaszkolnych. 
Obligatoryjny element postępowania akredytacyjnego stanowi, w myśl rozporządzenia, tzw. wizyta akredytacyjna, którą zespół składa $\mathrm{w}$ miejscu prowadzenia kształcenia zgłoszonego do akredytacji $\mathrm{w}$ celu oceny rzeczywistego stanu, w jakim kształcenie się odbywa. Przewodniczący zespołu ma obowiązek powiadomić o programie i terminie wizyty osobę kierującą placówką, a w przypadku oświatowej działalności gospodarczej - osobę prowadzącą tę działalność, ponadto zaś organ prowadzący placówkę. Informację o terminie przewodniczący przekazuje również członkom zespołu akredytacyjnego ${ }^{29}$.

Pierwszym etapem oceny jest analiza formalna złożonych dokumentów. W przypadku gdy złożony wniosek wraz z załącznikami nie spełnia wymogów formalnych, kurator oświaty zwraca się na piśmie do osoby kierującej placówką o usunięcie stwierdzonych braków w wyznaczonym terminie. W kolejnym etapie przedmiotowa ocena dokonywana jest $\mathrm{w}$ oparciu o treść wniosku i dołączone do niego dokumenty oraz na podstawie stanu faktycznego zastanego $w$ trakcie wizyty akredytacyjnej $w$ miejscach prowadzenia kształcenia zgłoszonego do akredytacji ${ }^{30}$. Trzeba zwrócić uwagę, że przy wyznaczaniu zakresu akredytacji ustawodawca działa niezwykle przychylnie w odniesieniu do osoby występującej o dokonanie oceny, bowiem o programie i terminie wizyty akredytacyjnej wnioskujący zostaje powiadomiony co najmniej na siedem dni przez planowaną akredytacją. Jest to okres, w którym mogą zostać przeanalizowane wszelkie kwestie wymagające szczególnej uwagi i względnych poprawek. W trakcie dokonywania oceny członkowie zespołu akredytacyjnego mogą zwracać się do podmiotu prowadzącego placówkę o udzielanie dodatkowych informacji dotyczących działalności placówki w zakresie zgłoszonym do akredytacji. Tego typu szerokie traktowanie problematyki akredytowania powinno także działać na korzyść podmiotu wnioskującego o akredytację. Daje bowiem możliwość zaprezentowania komisji wszelkich argumentów przemawiających na korzyść placówki oraz ewentualność obrony przy potencjalnych uchybieniach w działaniach.

Jeżeli placówka organizuje formy doskonalenia również poza siedzibą główną, zespół akredytacyjny może przeprowadzić wizytę akredytacyjną

${ }^{29} \S 6$ pkt 2 rozporządzenia w sprawie akredytacji kształcenia ustawicznego w formach pozaszkolnych.

$30 \S 6$ rozporządzenia w sprawie akredytacji kształcenia ustawicznego w formach pozaszkolnych. 
także w miejscach, w których te formy doskonalenia są organizowane. W następstwie przedstawionych wyżej czynności zespół akredytacyjny ustala ocenę jej działalności. Dokonuje tego w drodze głosowania zwykłą większością głosów, w obecności co najmniej połowy członków składu zespołu $^{31}$. Ponieważ przepisy prawa nie precyzują, w jakiej formie powinno się odbyć głosowanie, zatem należy przyjąć, że ma ono postać głosowania jawnego. Tego typu głosowania często bywają poprzedzone dyskusją i formułowaniem określonych wniosków, co bez wątpienia może sprzyjać podmiotowi wnioskującemu o przeprowadzenie oceny. W przypadku równej liczby głosów w głosowaniu ostatecznie decydujący jest głos przewodniczącego komisji. Zgodnie z powszechnie stosowanymi procedurami z przebiegu prac zespołu akredytacyjnego sporządza się protokół, który podpisują wszyscy członkowie zespołu ${ }^{32}$.

Po zakończeniu prac zespołu akredytacyjnego przewodniczący zespołu niezwłocznie przekazuje kuratorowi oświaty protokół oraz dokumenty, które zostały dołączone do wniosku o akredytację. Na tej podstawie kurator oświaty właściwy dla siedziby placówki lub ośrodka wydaje decyzję o przyznaniu lub odmowie przyznania placówce akredytacji33. Pomimo zadań jakie wykonuje zespół akredytacyjny, należy mieć na uwadze, że jest on jedynie ciałem pomocniczym, ustalającym dla potrzeb kuratora ocenę prowadzonej działalności szkoleniowej wnioskującego podmiotu, która pozwala mu na podjęcie decyzji w sprawie ${ }^{34}$.

Ustawa nie nakłada na kuratora obowiązku przeprowadzania okresowej kontroli, mającej na celu sprawdzanie stanu akredytowanych placówek. Może zatem mieć miejsce sytuacja, w której placówka kształcenia ustawicznego posiadająca akredytację w określonym momencie de facto przestała spełniać któryś z warunków niezbędnych do jej uzyskania, zaś

$31 \S 9$ ust. 1 rozporządzenia w sprawie akredytacji kształcenia ustawicznego w formach pozaszkolnych.

${ }^{32} \S 9$ ust. 3 rozporządzenia w sprawie akredytacji kształcenia ustawicznego w formach pozaszkolnych.

33 Co do zasad zwolnień podatkowych odnoszących się do placówek, które uzyskały akredytację zob. A. Bartosiewicz, VAT. Komentarz, wyd. 8, Warszawa 2014, s. 620. Por. Wyrok WSA w Gliwicach z dnia 2 lipca 2008 r., I SA/Gl 216/08, http:/ /orzeczenia.nsa.gov. pl/doc/B88E222C74 [dostęp: 18.01.2020 r.].

34 Por. Wyrok WSA w Warszawie z dnia 7 marca 2012 r., II SA/Wa 2297/11, http://www.orzeczenia-nsa.pl/wyrok/ii-sa-wa-2297-11/oswiata/13d60d7.html [dostęp: 10.09.2019 r.]. 
formalnie nadal jest $\mathrm{w}$ posiadaniu akredytacji. Brak wytycznych $\mathrm{w}$ tym zakresie co do zasady wyraźnie dyskredytuje instytucję akredytowania. Zatem kolejna uwaga de lege ferenda odnosi się do konieczności nałożenia na kuratora oświaty obowiązku przeprowadzania kontroli w placówkach wcześniej akredytowanych.

Jeżeli jednak kurator oświaty stwierdzi, że placówka albo inny podmiot prowadzący kształcenie ustawiczne $\mathrm{w}$ formach pozaszkolnych nie spełnia co najmniej jednego z warunków wymaganych do uzyskania akredytacji, ma obowiązek powiadomić o tym dyrektora placówki oraz organ prowadzący placówkę, a w przypadku innego podmiotu prowadzącego kształcenie ustawiczne $\mathrm{w}$ formach pozaszkolnych - osobę reprezentującą ten podmiot, oraz wyznacza placówce albo temu podmiotowi termin do usunięcia uchybień w tym zakresie nie krótszy niż 14 dni ${ }^{35}$.

Kurator oświaty może również zobowiązać placówkę albo inny podmiot prowadzący kształcenie ustawiczne w formach pozaszkolnych do przedstawienia $\mathrm{w}$ tym terminie ponownie własnej oceny opracowanej przez dyrektora placówki albo osobę reprezentującą ten podmiot. Jeżeli placówka albo inny podmiot prowadzący kształcenie ustawiczne $\mathrm{w}$ formach pozaszkolnych $\mathrm{w}$ terminie wyznaczonym przez kuratora oświaty nie usunie uchybień, kurator oświaty może cofnąć akredytację na prowadzenie kształcenia ustawicznego w danej formie pozaszkolnej, której dotyczą uchybienia ${ }^{36}$.

Podstawy wydania decyzji administracyjnej dotyczące cofnięcia akredytacji są analogiczne jak w przypadku jej przyznania ${ }^{37}$. Przed cofnięciem akredytacji kurator oświaty może zasięgnąć opinii zespołu akredytacyjnego, jednak do zasięgnięcia przedmiotowej opinii nie jest niczym zobligowany. O cofnięciu akredytacji kurator oświaty niezwłocznie powiadamia

35 Warto pamiętać, że z uwagi na odmienne funkcje oświatowe organ prowadzący placówkę jest autonomiczny w stosunku do organu, jakim jest kurator oświaty. Jednak, jeśli kurator stwierdzi, że spełnianie przez placówkę kształcenia ustawicznego zachodzi z uchybieniami, przepis wyraźnie uprzywilejowuje funkcje nadzorcze kuratora oświaty wobec organu prowadzącego. E. Pierzchała, J. Pierzchała, Oświata w sferze ustug publicznych, w: Administracja dóbr i ustug publicznych, red. M. Woźniak, Warszawa 2013, s. 122.

36 § 13 rozporządzenia $\mathrm{w}$ sprawie akredytacji kształcenia ustawicznego $\mathrm{w}$ formach pozaszkolnych.

37 Por. Komentarz do tezy 4 art. 118, Prawo oświatowe oraz przepisy wprowadzajace. Komentarz, red. M. Pilich, A. Olszewski, Warszawa 2017, https://sip.lex.pl/\#/commentary /587750401/547841?keyword=Pilich\&tocHit=1\&cm=STOP [dostęp: 20.10.2019 r.]. 
organ prowadzący placówkę oraz ministra właściwego do spraw oświaty i wychowania. Placówka, której kurator oświaty cofnął akredytację, może ubiegać się ponownie o jej przyznanie nie wcześniej niż po upływie roku od dnia cofnięcia akredytacji ${ }^{38}$.

\section{Zakończenie}

Konkludując, odnośnie do przepisów prawa, które regulują problematykę kształcenia ustawicznego oraz akredytacji, należy zwrócić uwagę, że poddanie się ocenie mające na celu uzyskanie akredytacji placówki przynosi wiele korzyści zarówno po stronnie wnioskującego, jak i potencjalnych uczestników kształcenia. W pierwszym przypadku akredytowana placówka legitymuje się urzędowo potwierdzoną wysoką jakością świadczonych usług, a tym samym daje gwarancję jakości kształcenia. Ponadto placówka staje się bardziej konkurencyjna na runku usług edukacyjnych. Trzeba też wspomnieć o wzroście jej prestiżu i zaufania do niej osób kształcących się. Dla potencjalnych klientów akredytacja oznacza możliwość korzystania z usług edukacyjnych na wysokim poziomie i uzyskanie świadectwa wydanego przez wiarygodną placówkę. To zaś będzie się przekładać na zwiększenie szansy zatrudnienia lub uzyskania wyższego stanowiska pracy.

Biorąc pod uwagę powyższe, należy uznać, że fakt otrzymania akredytacji wiąże się bezsprzecznie z licznymi korzyściami dla placówki, występującymi nie tylko doraźnie, ale także w długiej perspektywie. Akredytacja bowiem jest najskuteczniejszym wymiernym narzędziem jakości kształcenia, swoistym znakiem jakości. Wobec tych obiektywnych przesłanek zupełnie niezrozumiałe jest stanowisko ustawodawcy, który - jak się wydaje - nie dostrzega istoty zagadnienia akredytowania rynku usług edukacyjnych. Świadczy o tym zapis w kształcie: „Placówka kształcenia ustawicznego i centrum kształcenia zawodowego może uzyskać akredytację na kształcenie ustawiczne prowadzone w formie pozaszkolnej"39. W ślad za tym podążyło orzecznictwo, formułując tezę, że „Ubieganie się o przyznanie akredytacji nie jest obligatoryjne, jest pewną możliwością,

$38 \S 13$ ust. 3 rozporządzenia w sprawie akredytacji kształcenia ustawicznego w formach pozaszkolnych.

39 Art. 118 ust. 1 ustawy z dnia 14 grudnia 2016 r. - Prawo oświatowe. 
jaką przewidują przepisy prawa oświatowego, a sama decyzja $\mathrm{w}$ tej sprawie jest wydawana przez kuratora oświaty $\mathrm{w}$ ramach uznania administracyjnego" ${ }^{40}$. Obowiązujące przepisy podtrzymały fakultatywność ubiegania się o akredytację przez placówki kształcenia ustawicznego. Nie tylko zresztą nie skorzystano ze zmiany tego stanowiska przy okazji reformy oświatowej z 2017 r., ale nastąpił znaczny regres. Zgodnie z uchylonym już ust. 4 art. 118 ustawy Prawo oświatowe w postępowaniu o uzyskanie akredytacji kurator oświaty musiał uwzględnić także wyniki nadzoru pedagogicznego sprawowanego nad placówką lub ośrodkiem. Rozwiązania te nie dopuszczały do uzyskania akredytacji przez placówkę nowo tworzoną, czyli de facto jeszcze niespełniającą wymogów formalnych do jej uzyskania. $\mathrm{W}$ obecnym stanie prawnym kurator nie ma takiego obowiązku, co może powodować, że nawet niska ocena uzyskana w wyniku procedury nadzorczej nie dyskwalifikuje placówki do ubiegania się i uzyskania znaku jakości, jakim jest akredytacja.

Uwagę zwraca także fakt, że ustawodawca nie nałożył na kuratora oświaty obowiązku przeprowadzania okresowej kontroli tych placówek, które uzyskały akredytację wcześniej. Konsekwencją takiego rozwiązania może być sytuacja, w której placówka kształcenia ustawicznego z jakichś powodów przestała spełniać któryś z warunków niezbędnych do uzyskania (posiadania) akredytacji, formalnie zaś nadal jest w jej posiadaniu.

Przedstawione tu argumenty wskazują na istotną wartość akredytacji z punktu widzenia jakości kształcenia placówek kształcenia ustawicznego,

40 Wyrok WSA w Warszawie z dnia 7 marca 2012 r., II SA/Wa 2297/11, http:/ / www. orzeczenia-nsa.pl/wyrok/ii-sa-wa-2297-11/oswiata/13d60d7.html [dostęp: 10.08.2019 r.]. Zgodnie z art. 103 ustawy z dnia 22 listopada 2018 r. o zmianie ustawy - Prawo oświatowe, ustawy o systemie oświaty oraz niektórych innych ustaw (Dz. U. z 2018 r. poz. 2245): „Akredytacja kuratora oświaty przyznana przed dniem 1 września 2019 r. na podstawie art. 118 ust. 2 ustawy Prawo oświatowe w brzmieniu dotychczasowym, zachowuje moc do zakończenia kształcenia ustawicznego w danej formie pozaszkolnej, nie dłużej niż do dnia 31 grudnia 2020 r. Postępowania o przyznanie akredytacji na kształcenie ustawiczne prowadzone $\mathrm{w}$ formie pozaszkolnej złożone i nierozpatrzone przed dniem 1 września 2019 r., rozpatruje się zgodnie z przepisami art. 118 ustawy Prawo oświatowe w brzmieniu nadanym ustawą z dnia 22 listopada 2018 r. o zmianie ustawy - Prawo oświatowe, ustawy o systemie oświaty oraz niektórych innych ustaw. Wnioskodawca dostosuje wniosek do wymagań określonych w art. 118 ust. 3 ustawy Prawo oświatowe w brzmieniu nadanym ustawą z dnia 22 listopada 2018 r. o zmianie ustawy - Prawo oświatowe, ustawy o systemie oświaty oraz niektórych innych ustaw, do dnia 31 grudnia 2019 r.". 
będących częścią systemu oświaty. Właśnie jakość kształcenia, która stanowi podstawę każdej instytucji oświatowej, jest bezsprzecznym determinantem tego, żeby akredytacja była obligatoryjnym składnikiem tych instytucji. Z całą stanowczością należy jednak podkreślić, że wprowadzenie obligatoryjności musiałoby być poprzedzone zmianami przepisów prawnych. Już dzisiaj bowiem są one mało precyzyjne, co ewidentnie powoduje obniżenie rangi akredytacji, a co za tym idzie akredytowanych placówek.

\section{Bibliografia}

\section{Źródła}

\section{Akty prawne}

Rozporządzenie Ministra Edukacji Narodowej z dnia 1 sierpnia 2017 r. w sprawie szczegółowych kwalifikacji wymaganych od nauczycieli, Dz. U. z 2017 r. poz. 1575.

Rozporządzenie Ministra Edukacji Narodowej z dnia 25 sierpnia 2017 r. w sprawie nadzoru pedagogicznego, Dz. U. z 2017 r. poz. 1658 z późń. zm.

Rozporządzenie Ministra Edukacji Narodowej z dnia 14 lutego 2019 r. w sprawie ramowych statutów: publicznej placówki kształcenia ustawicznego oraz publicznego centrum kształcenia zawodowego, Dz. U. z 2019 r. poz. 320.

Rozporządzenie Ministra Edukacji Narodowej z dnia 19 marca 2019 r. w sprawie kształcenia ustawicznego w formach pozaszkolnych, Dz. U. z 2019 r. poz. 652.

Rozporządzenie Ministra Edukacji Narodowej z dnia 29 sierpnia 2019 r. w sprawie akredytacji kształcenia ustawicznego w formach pozaszkolnych, Dz. U. z 2019 r. poz. 1692.

Ustawa z dnia 26 stycznia 1982 r. - Karta Nauczyciela, Dz. U. z 2018 r. poz. 967.

Ustawa z dnia 14 grudnia 2016 r. - Prawo oświatowe, tekst jednolity: Dz. U. z 2019 r. z późn. zm.

Ustawa z dnia 22 listopada 2018 r. o zmianie ustawy - Prawo oświatowe, ustawy o systemie oświaty oraz niektórych innych ustaw, Dz. U. z 2018 r. poz. 2245.

\section{Orzecznictwo}

Wyrok WSA w Gliwicach z dnia 2 lipca 2008 r., I SA/G1 216/08, http:/ / orzeczenia.nsa.gov.pl/doc/B88E222C74 [dostęp: 20.08.2019 r.].

Wyrok WSA w Warszawie z dnia 3 października 2008 r., I SA/Wa 638/08, LEX nr 521226. 
Wyrok WSA w Warszawie z dnia 7 marca 2012 r., II SA/Wa 2297/11, http:/ / www.orzeczenia-nsa.pl/wyrok/ii-sa-wa-2297-11/oswiata/13d60d7.html [dostęp: 20.08.2019 r.].

\section{Pozostałe źródła}

Modelowy program nauczania dla kwalifikacyjnego kursu zawodowego w zakresie kwalifikacji A.35. Kształcenie ustawiczne w formach pozaszkolnych. Program o strukturze modułowej, https://efs.men.gov.pl/wp-content/uploads/2018/04/A.35.pdf [dostęp: 01.09.2019 r.].

Ministerstwo Edukacji Narodowej, Przewodnik procedur akredytacji placówek prowadzacych kształcenie ustawiczne w formach pozaszkolnych, Warszawa 2005.

\section{Literatura}

Bartosiewicz A., VAT. Komentarz, wyd. 8, Warszawa 2014.

Drogosz-Zabłocka E., Minkiewicz B., System zapewnienia jakości ksztatcenia, w: Edukacja dla pracy, red. U. Sztanderska, E. Drogosz-Zabłocka, B. Minkiewicz, Warszawa 2007.

Dziewulak D., Kształcenie na odległość w wybranych państwach europejskich, Analizy BAS 2012, t. 85, nr 18.

Halonen S.M., Lomas T., A passionate way of being. A qualitative study revealing the passion spiral, International Journal of Psychological Research 2014, t. 7, nr 2.

Jakubaszek W., Człowiek w kontekście całożyciowej edukacji. Teoria i praktyka. Wybrane zagadnienia, Kraków 2016.

Juszczyk S., Edukacja na odległość. Kodyfikacja pojęć, regut i procesów, Warszawa 2002.

Kształcenie zawodowe i ustawiczne a potrzeba rynku, red. B. Wołosiuk, M. Nowak, Biała Podlaska 2012.

Nowicki J., Wiśniewski P., Uczymy się przez całe życie. Przewodnik po kształceniu ustawicznym, Warszawa 2017.

Pierzchała E., Pierzchała J., Oświata w sferze ustug publicznych, w: Administracja dóbr i ustug publicznych, red. M. Woźniak, Warszawa 2013.

Pilich M., Ustawa o systemie oświaty. Komentarz, wyd. 5, Warszawa 2013.

Półturzycki J., Kształcenie ustawiczne i jego konsekwencje dla edukacji, w: Ksztatcenie ustawiczne. Idee i doświadczenia, red. Z.P. Kruszewski, J. Półturzycki, E.A. Wesołowska, Płock 2003.

Prawo administracyjne, red. M. Wierzbowski, wyd. 13, Warszawa 2017.

Prawo oświatowe oraz przepisy wprowadzajace. Komentarz, red. M. Pilich., A. Olszewski, Warszawa 2017.

Pyter M., Balicki A., Prawo oświatowe. Komentarz, Warszawa 2017.

Społeczne skutki zmiany oświatowej w Polsce, red. M. Niezgoda, Kraków 2011.

Szewior K., Akredytacja w niemieckim szkolnictwie wyższym, Warszawa 2018. 


\section{Streszczenie}

Akredytacja będąca gwarantem jakości jest odpowiedzią na rozwój globalny w wielu dziedzinach życia społecznego. Taką dziedziną jest również kształcenie. Stąd też placówki kształcenia legitymujące się posiadaniem certyfikatu stanowią wiarygodne miejsce zdobywania nowych kompetencji. W artykule podjęto się próby przedstawienia problematyki akredytacyjnej na kanwie obowiązujących przepisów prawa. Za pomocą metody analizy normy prawnej jednoznacznie wskazano na zasadność zarówno ubiegania się o akredytację, jak i jej uzyskiwania. W konkluzji sformułowano tezę, że w kontekście wartości, jaką jest akredytacja, powinna ona mieć cechy obligatoryjności, nie zaś - jak to jest w aktualnych przepisach prawa - jedynie fakultatywności.

Słowa kluczowe: placówki kształcenia ustawicznego, jakość kształcenia, akredytacja, prawo oświatowe

\section{ACCREDITATION OF THE EDUCATIONAL SERVICES MARKET. CURRENT LEGAL SOLUTIONS ON THE EXAMPLE OF LIFELONG LEARNING INSTITUTIONS}

\section{Summary}

Accreditation, which guarantees quality, embodies a response to the global development in many areas of the social life. Education is an analogous field. Therefore, the educational institutions awarded a certificate constitute a reliable place for acquiring new competences. The article attempts to present accreditation issues on the ground of the applicable law. Through analysis of the legal norms, the application of accreditation and the process of obtaining it, is presented in the paper. This leads to the conclusion that in the context of the value of accreditation, it should have the obligatory aspect rather than - as it is under currently binding law - only optional character.

Key words: Continuing education institutions, quality of education, accreditation, educational law 


\section{АККРЕДИТАЦИЯ РЫНКА ОБРАЗОВАТЕЛЬНЫХ УСЛУГ. АКТУАЛЬНЫЕ ПРАВОВЫЕ РЕШЕНИЯ НА ПРИМЕРЕ УЧРЕЖДЕНИЙ НЕПРЕРЫВНОГО ОБРАЗОВАНИЯ}

\section{Резюме}

Аккредитация, которая гарантирует качество, является ответом на глобальное развитие во многих сферах общественной жизни. Образование также является такой областью. Следовательно, образовательные учреждения, обладающие сертификатом являются надежным местом для приобретения новых компетенций. В статье предпринята попытка представить вопросы аккредитации на основе действующего законодательства. Используя метод анализа правовой нормы, была четко обозначена законность как подачи заявки на аккредитацию, так и ее получения. В заключении формулируется тезис в контексте значения аккредитации, а именно, что она должна иметь обязательный характер, а не - как это принято в действующем законодательстве - исключительно факультативный.

Ключевые слова: учреждения непрерывного образования, качество образования, аккредитация, образовательное право 